NICOLAS MOLL

\title{
Promoting 'Positive Stories' of Help and Rescue from the 1992-1995 War in Bosnia and Herzegovina. An Alternative to the Dichotomy of Guilt and Victimhood?
}

\begin{abstract}
Public discourses about wars and mass violence are often dominated by questions of guilt and victimhood as well as a focus on the figures of 'perpetrators' and 'victims'. This can also be observed concerning the public remembrance of the 1992-1995 conflict in Bosnia-Herzegovina. However, attempts were made here to promote the memory of another war-related figure: that of the rescuer who helped people 'from the other side'. The author analyses these attempts at remembrance in Bosnia-Herzegovina, and places them within the context of global efforts to publicly acknowledge rescuers, in particular the 'Righteous Among the Nations'.
\end{abstract}

Nicolas Moll holds a PhD in Contemporary History from the University of Freiburg i. Br. and works as an independent researcher in Sarajevo, Bosnia and Herzegovina.

\section{Introduction. The Memory of Rescuers vs the Memory of Victims and Perpetrators}

The focus on victims and perpetrators and, in this relation, the discussion about victimhood and guilt, has been a dominant pattern in public discourses in many contemporary societies dealing with a past of mass violence and atrocities. ${ }^{1}$ At the same time, in the public sphere in Europe and beyond, recent decades have seen interest grow in another category related to contexts of mass violence: the topic of help and rescue, in particular embodied in the figures of rescuers who helped endangered persons from other ethnic

${ }^{1}$ One striking case is the discussion about the Third Reich and the Holocaust in Germany. Cf., for example, Laurel Cohen-Pfister/Dagmar Wienröder-Skinner, eds, Victims and Perpetrators, 1933-1945. (Re)Presenting the Past in Post-Unification Culture, Berlin, New York/NY 2006. For other countries and other contexts, cf., for example, Sirkka Ahonen, Coming to Terms with a Dark Past. How Post-Conflict Societies Deal with History, Frankfurt et al. 2012, especially the chapters 'Arch Myths of Guilt and Victimhood', 20-23, and 'Dealing with Representations of Guilt and Victimhood in Finland, South Africa and Bosnia-Herzegovina', 59-148. 
or religious groups during the Second World War and other periods of mass violence.

The growing public attention on rescuers, and increased promotion of their memory, is illustrated by the fact that in the last 25 years many European states have officially acknowledged and institutionalized their tribute to the 'Righteous Among the Nations' from their own countries. This is based on the tribute given by the Israeli Holocaust Remembrance Center Yad Vashem to the non-Jews who saved Jews from Nazi extermination during the Second World War. ${ }^{2}$ However, public interest in rescuers extends to other historical events: the European Parliament, for example, in 2012 supported the creation of a 'European Day of Remembrance for the Righteous' which refers to 'those who helped the Jews during the Holocaust' as well as to 'people who saved lives during all genocides and mass murders (such as the Armenian, Bosnian, Cambodian and Rwandan ones) and the other crimes against humanity perpetrated in the 20th and 21st centuries'. ${ }^{3}$

Academic research, too, has in the last three decades increasingly turned its attention to rescuers and acts of rescue in contexts of mass violence. ${ }^{4}$ Part of this research has focused on the memorialization of these rescuers in different countries since 1945, mainly referring to the rescue of Jews during the Holocaust, ${ }^{5}$ but also to other contexts of mass violence, especially in Rwanda and Armenia. ${ }^{6}$

${ }^{2}$ Cf. Sarah Gensburger, Les Justes de France. Politiques publiques de la mémoire, Paris 2010.

${ }^{3}$ European Parliament, Declaration of the European Parliament of 10 May 2012 on Support for the Establishment of a European Day of Remembrance for the Righteous, 10 May 2012, http://www.europarl.europa.eu/sides/getDoc.do?pubRef=-//EP//TEXT+TA+P7TA-2012-0205+0+DOC+XML+V0//EN. All internet references were accessed on 6 December 2019.

${ }^{4}$ For an overview of research on the rescue of Jews during the Second World War, cf. for example Jacques Semelin, Introduction. From Help to Rescue, in: Jacques Semelin/Claire Andrieu / Sarah Gensburger, eds, Resisting Genocide. The Multiple Forms of Rescue, London 2011, 1-14; Suzanne Beer, Aid Offered Jews in Nazi Germany. Research Approaches, Methods, and Problems, Online Encyclopedia of Mass Violence, 22 September 2014, https://www. sciencespo.fr/mass-violence-war-massacre-resistance/en/document/aid-offered-jews-nazigermany-research-approaches-methods-and-problems; Christian Gudehus, Helping the Persecuted. Heuristics and Perspectives (Exemplified by the Holocaust), Online Encyclopedia of Mass Violence, 7 March 2016, http://www.sciencespo.fr/mass-violence-war-massacreresistance/en/document/helping-persecuted-heuristics-and-perspectives-exemplifiedholocaust.

${ }^{5}$ For example, cf. Johannes Tuchel, Der ignorierte Widerstand. Entwicklung und Perspektiven der Erinnerung an die 'Stillen Helden', in: Stiftung Gedenkstätte Deutscher Widerstand, ed, Liebe Inge, herzlich. Festschrift für Inge Deutschkron zum 90. Geburtstag, Berlin 2012, 140-162.

${ }^{6}$ For example, cf. the contributions in Semelin/Andrieu/Gensburger, eds, Resisting Genocide. 
In comparison, academic research on interethnic help and rescue during the 1992-1995 war in Bosnia-Herzegovina remains underdeveloped. The issue has mainly been treated as a subtopic, for example within broader anthropological research on everyday life during the siege in Sarajevo, ${ }^{7}$ and also in research on 'bystanders' during the Bosnian war and relations between neighbours in Bosnian society. ${ }^{8}$ However, the memorialization of help and rescue has attracted some scholarly attention. Ron Dudai has reflected on the functions and practices of rescuer commemoration for transitional justice purposes. ${ }^{9}$ I myself have analysed representations of help and rescue in feature films about the Bosnian war, and have focused on the remembrance of an individual rescuer. ${ }^{10}$ In the following, I develop this research further: I analyse public discourses in Bosnia-Herzegovina on interethnic help and rescue during the 1992-1995 war, focusing on the entanglements of the memorialization of rescuers with public discussion about guilt and victimhood in the same context.

These entanglements are also central in the processes of memorialization of rescuers in other countries and concerning other periods of mass violence. For example, Sarah Gensburger has shown that in France the emergence of an institutionalized memory of the 'Righteous of France' was intrinsically tied to the discussion and recognition of the responsibilities of the French state in the deportation of the Jews. The remembrance of the French rescuers developed as a direct counterpart to the acknowledgement of French complicity in the Holocaust. ${ }^{11}$ In other cases, such as those of Poland or Italy, the contrary can be observed: for several decades, rescuers were commemorated in order to avoid any debate regarding Polish or Italian responsibilities for crimes. ${ }^{12}$

\footnotetext{
7 Ivana Maček, Sarajevo Under Siege. Anthropology in Wartime, Philadelphia/PA 2009, 79-80, 86-89, 105-111.

${ }^{8}$ Iva Lučić, Bystanders in Bosnia and Herzegovina during the Conflict in the 1990s, Politička Misao. Croatian Political Science Review 50, no. 5 (2013), 29-53, 49-51, https://hrcak. srce.hr/file/171112; Bojan Baskar, Komšiluk and Taking Care of the Neighbor's Shrine in Bosnia-Herzegovina, in: Dionigi Albera/Maria Couroucli, eds, Sharing Sacred Spaces in the Mediterranean. Christians, Muslims, and Jews at Shrines and Sanctuaries, Bloomington/IN 2012, 51-68, 65-67.

9 Ron Dudai, 'Rescuers for Humanity'. Rescuers, Mass Atrocities and Transitional Justice, Human Rights Quarterly 34, no. 1 (2012), 1-38, DOI: 10.1353/hrq.2012.0018.

${ }_{10}$ Nicolas Moll, 'When A Man Does Good...'. Representations of Help and Rescue in Movies about the 1992-1995 War in Bosnia and Herzegovina, DIOGEN pro culture magazine, Special Book of Proceedings from the 1st International Symposium on Culture of Remembrance BiH, 1 September 2015, 7-18; Nicolas Moll, A Positive Hero for Everyone? The Memorialization of Srđan Aleksić in Post-Yugoslav Countries, Contemporary Southeastern Europe 3, no. 1 (2016), 1-31, http://www.contemporarysee.org/en/moll.

${ }^{11}$ Gensburger, Les Justes de France, 73-99.

${ }^{12}$ On Poland, cf. Gensburger, Les Justes de France, 144-158; for the case of Italy Paola Bertilotti, Italian Jews and the Memory of Rescue, 1944-1961, in: Semelin / Andrieu / Gensburger, eds, Resisting Genocide, 127-133.
} 
Public discussions about movies based on rescuer stories, such as 'Schindler's List' or 'Hotel Rwanda', regularly feature voices claiming that these films trivialize or distract from mass atrocities, thus relativizing guilt and responsibility. In contrast, opposing voices argue that the films draw attention to the crimes, the victims and to related questions, such as the passivity of so-called 'bystanders'. ${ }^{13}$

In this study, I discuss these questions in relation to Bosnia-Herzegovina and partially also to other countries in the post-Yugoslav space. I will proceed in five steps: firstly, I will provide an overview of the efforts undertaken by civil society actors to promote stories of interethnic help and rescue in relation to the 1992-1995 war. Secondly, I will analyse the motives of people and organizations working to preserve the memory of helpers and rescuers from the Bosnian war, demonstrating how they are strongly driven by the aspiration to overcome the dichotomy of guilt and victimhood. Thirdly, I will look at responses to these memorialization efforts, highlighting how difficult it is to escape the dichotomy mentioned above. Fourthly, I will compare discourses about rescue(rs) in the war in Bosnia-Herzegovina with those relating to other contexts of mass violence in order to see how they differ in regard to linking rescue to the topics of guilt and victimhood. And finally, I will synthesize my findings: to what extent do rescue(r) stories have the potential to go beyond perpetrator/victim patterns? In sum, I aim to integrate rescuer discourses from Bosnia-Herzegovina into a European and global context, and thereby contribute to the general discussion about the possibilities and challenges of the memorialization of help(ers) and rescue(rs) in contemporary societies.

\section{Initiatives to Promote the Memory of Helpers and Rescuers since 1995}

Attempts to publicly remember persons who helped and rescued people 'from the other side' during the Bosnian war started very soon after the end of the war in 1995. Two parallel initiatives stand out. Svetlana Broz, a cardiologist and granddaughter of Yugoslav president Josip Broz Tito, on the one hand, and civil society activists Jezdimir and Snežana Milošević with their association Protektor on the other, collected 'positive stories' about cross-ethnic solidarity, help and rescue during the war. This resulted in the publication of

\footnotetext{
${ }^{13}$ On the debate around 'Schindler's List', cf. Yosefa Loshitzky, ed, Spielberg's Holocaust. Critical Perspectives on Schindler's List, Bloomington/IN 1997; William J. Niven, The Reception of Steven Spielberg's Schindler's List in the German Media, Journal for European Studies 23, no. 2 (1995), 165-189, DOI: 10.1177/004724419502500204.
} 
two books in Bosnia and Herzegovina in 1999: 'Good People in an Evil Time'14 and 'Light in the Tunnel'15. Subsequently, in 2001 Svetlana Broz founded the association Gariwo in Sarajevo, which since then, amongst other activities, has advocated the idea of the creation of a 'Garden of the Righteous of the Bosnian War' in Sarajevo, modelled on Yad Vashem. ${ }^{16}$

Since then, other initiatives have also developed. Between 2001 and 2005, sociologist Džemal Sokolović conducted a project collecting testimonies 'about good deeds performed across ethnic/religious lines in the course of the war in Bosnia'. ${ }^{17}$ On the basis of his findings, in 2006 he made the documentary film 'And There Was Light ...' which presented three such cases. ${ }^{18}$ In 2010, the non-governmental organization 'Research and Documentation Center' (RDC) in Sarajevo published the book 'The Signals of Heart', presenting further 'positive stories' from the war. ${ }^{19}$ In 2011, the NGO 'Post-Conflict Research Center' (PCRC), also based in Sarajevo, launched the project 'Ordinary Heroes', which included the production of documentaries on Bosnian-Herzegovinian rescuers. ${ }^{20}$ From 2014 to 2015, the 'Independent Journalists' Association of Vojvodina' (Nezavisno društvo novinara Vojvodine) and the 'Association of BH Journalists' (BH Novinari) realized the project 'Living Together', producing five documentaries mainly about persons from Bosnia-Herzegovina and Serbia who helped and rescued others during the war. ${ }^{21}$ Stories of wartime

${ }^{14}$ Svetlana Broz, Dobri ljudi u vremenu zla, Banja Luka 1999; English edition: Good People in an Evil Time. Portraits of Complicity and Resistance in the Bosnian War, New York/NY 2005; French edition: Des gens de bien au temps du mal. Témoignages sur le conflit bosniaque, 1992-1995, Panazol 2005.

15 Jezdimir Milošević/ Snežana Milošević, Svetla u tunelu, Sarajevo 1999. All quotes from non-English sources were translated by N. M.

${ }^{16}$ Cf. the website of Gariwo, www.gariwo.org.

${ }_{17}$ For more on Džemal Sokolović and his project, see his LinkedIn profile, https://www. linkedin.com/in/dzemal-sokolovic-3b951116/?originalSubdomain=no.

${ }^{18}$ This documentary film is not available to the public. I watched it during a conference screening in Sarajevo in April 2014. For Džemal Sokolović's introductory words on the occasion of the screening, cf. And There Was Light. Ist Symposium - Culture of Remembrance, 12-13 April 2014, Sarajevo, YouTube, https://www.youtube.com/watch?v=tm649Dw34DE.

${ }^{19}$ Research and Documentation Centre (RDC), Signali srca / The Signals of Heart, Sarajevo 2010 (bilingual edition).

${ }^{20}$ For more information about this project, cf. Tim Bidley, Post-Conflict Research Center Wins Intercultural Innovation Award, peaceinsight.org, 10 September 2014, https://www. peaceinsight.org/es/blog/2014/09/post-conflict-research-center-wins-intercultural-innovationaward/?en=1; Post-Conflict Research Center (PCRC), https://www.p-crc.org/.

${ }^{21}$ Cf. the website Nezavisno društvo novinare Vojvodine, Projekt 'Živeti zajedno', http:// www.ndnv.org/projekti/2014-2/projekat-ziveti-zajedno/. The videos can be viewed (partially with English subtitles) at https://vimeo.com/zivetizajedno. Another media project was launched in 2017 by the news portal Frontal based in Banja Luka with the title 'Human Examples in an Inhuman War'. It collected video testimonies of help and rescue during the war. Various articles and videos can be found on the website Humani primjeri nehumanog 
help and rescue have been publicized within other civil society projects, too, where the main topic has been a different one. One such example is the project 'Choosing Peace Together', implemented between 2010 and 2014 with the participation of members of victims associations. ${ }^{22}$ Similarly, one of the main aims within the framework of the initiative to create a 'Truth and Reconciliation Commission' (TRC) in Bosnia-Herzegovina, promoted by various civil society actors between 1997 and 2006, was to document and publicize positive stories of interethnic help and rescue during the war. Although the TRC never materialized, this interest in rescuer stories is noteworthy, even more so as this was a deliberate innovation in comparison with the agendas of Truth and Reconciliation Commissions in other countries. ${ }^{23}$

However, the enumeration of these efforts should not lead to the conclusion that stories of help and rescue during the war are well known, widespread, and well accepted within Bosnia-Herzegovina and the larger post-Yugoslav space. The contrary is more commonly the case. An observer summarized the attitude in Bosnia-Herzegovina in 2016: 'Good people remain in silence'. ${ }^{24}$ At the same time, the aforementioned efforts do reach part of the public. The book 'Good People in an Evil Time', for example, has seen several editions since its first publication in 1999. Public activities such as film screenings and conferences have attracted up to several hundred people. ${ }^{25}$ However, the following must be pointed out: all the above-mentioned initiatives were launched and developed by civil society actors, while the state and other public authorities

rata, Frontal, http://www.frontal.ba/kategorija/134/humani-primjeri. In 2018, a DVD with a documentary film of 65 minutes in length was released, titled 'Humani primjeri nehumanog rata' (DVD in possession of the author).

${ }_{22}$ On the project 'Choosing Peace Together', cf. for example Atalia Omer, Bridging Ethnoreligious Divides in Bosnia and Herzegovina, Contending Modernities Blog, 3 October 2016, https://sites.nd.edu/contendingmodernities/2016/10/03/bridging-ethnoreligious-dividesin-bosnia-and-herzegovina-choosing-peace-together-through-interreligious-action-forconflict-transformation/.

${ }^{23}$ On the TRC initiative and the reasons why it did not succeed, cf. Jasna Dragović-Soso, History of a Failure. Attempts to Create a National Truth and Reconciliation Commission in Bosnia and Herzegovina, 1997-2006, International Journal of Transitional Justice 10, no. 2 (2016), 292-310, DOI: 10.1093/ijtj/ijw005. On rescuers within this initiative, cf. Dragović-Soso, History of Failure, 299; Dudai, 'Rescuers for Humanity', 18-19. Original documents relating to the TRC initiative (press releases, reports, etc.) can be found at the Association of Citizens, Truth and Reconciliation, http://www.angelfire.com/bc2/kip/engleski.html.

${ }^{24}$ Nataša Gaon-Grujić, Dobri ljudi ostanu u tišini, Aljazeera Balkans, 9 April 2016, http:// balkans.aljazeera.net/blog/dobri-ljudi-ostanu-u-tisini.

${ }^{25}$ It is also noteworthy that Al Jazeera Balkans included the 'Ordinary Heroes' documentary by the Post-Conflict Research Center in its regional programme, cf. Dokumentarni film. Obični heroji, Aljazeera Balkans, 25 January 2016, http://balkans.aljazeera.net/vijesti/ dokumentarni-film-obicni-heroji. According to the PCRC, the documentary reached one million viewers across the Western Balkans. PCRC, Ordinary Heroes, n.d., http://www. p-crc.org/our-projects/ordinary-heroes. 
have remained uncommitted and have shown no interest in supporting these initiatives or in developing activities themselves. ${ }^{26}$ For instance, Gariwo's project to build a 'Garden of the Righteous of the Bosnian War' never gathered sufficient political support to be implemented. ${ }^{27}$ Another illustration of the lack of support by public authorities for (civil society) initiatives is the fact that in 2017 the municipality of Novi Grad in Sarajevo turned down the proposal to name a new sports hall in the Grbavica neigbourhood after Goran Čengić, a former professional handball player who was killed in 1992 while trying to protect a Muslim neighbour. ${ }^{28}$ Similarly, help and rescue during the Bosnian war has remained a marginalized topic in the mainstream media. Even within the NGO sector, the initiatives named above have remained rather isolated. Furthermore, hardly any contact and even less coordination efforts exist between the various initiatives, reflecting the general fragmentation and level of competition within the civil society sector in Bosnia, which is sometimes guided by personal rivalries between various protagonists. ${ }^{29}$

Generally, outside of certain civil society circles it remains difficult to talk about help and rescue in the public sphere both in Bosnia-Herzegovina and the larger post-Yugoslav sphere. During the war, the dominant nationalist forces generally treated individuals who helped or rescued persons from another ethnic group as traitors. Given that rescuers faced very negative reactions when acting openly or when they were caught, they resorted to secrecy. After the war, their fear persisted: initiatives that collected stories about rescue have noted how people they contacted were often concerned about going public. In 2006, Svetlana Broz observed that the situation had improved in comparison to the period immediately after the war. ${ }^{30}$ Yet, other experiences indicate that people were still afraid to tell stories of help and rescue. When the Research and Documentation Center conducted its project between 2007

\footnotetext{
${ }^{26}$ Significantly, the mentioned civil society activities have been mainly financed by international donors, such as the Swiss and Norwegian ministries of foreign affairs.

${ }^{27}$ On the efforts and difficulties of establishing a 'Garden of the Righteous' in Bosnia-Herzegovina, cf. for example the interview with Svetlana Broz, The Righteous Will Help Bosnia, Gariwo, 23 May 2012, https://en.gariwo.net/righteous/european-day-of-the-righteous/ the-righteous-will-help-bosnia-5099.html.

${ }^{28}$ Cf. Gordana Sandić-Hadžihasanović, Nema mjesta za heroja, Slobodna Evropa, 28 September 2017, https://www.slobodnaevropa.org/a/goran-Čengić-hala/28762497.html.

${ }^{29}$ For a general overview, cf. Chiara Milan, Civil Society in Bosnia Herzegovina. From the Late ' 80 s to Nowadays. A Historical Perspective, Revista de Historia Actual 4, no. 2 (2017), 272-296, http://revistes.uab.cat/tdevorado/article/view/v4-n2-milan. Among the pioneers of efforts to acknowledge those who helped and rescued, Svetlana Broz and Jezdimir Milošević both supported the TRC BiH initiative and its idea to document 'positive examples'. Given that this initiative did not materialize, neither did further cooperation between them.

${ }^{30}$ Svetlana Broz, The Best Among Us, in : Svetlana Broz/Thomas Butler, eds, Having What it Takes. Essays on Civil Courage, Sarajevo 2006, 101-107.
} 
and 2009, 56 of the contacted 125 persons involved in acts of help refused to be interviewed. Of the 69 who agreed, one quarter asked to remain anonymous. ${ }^{31}$ People refused to participate,

'citing fears for the safety of the people who helped them during the war [...]. Most often these people still live in environments where helping people of other ethnicities is not viewed in a positive way, and some of them already had problems during the war, as well as later on. According to our findings, they and their families were often denigrated in the environment in which they live, and sometimes subjected to physical and verbal attacks as well as threats; some of them were also considered as national traitors. ${ }^{32}$

Obviously, the general sociopolitical context in Bosnia-Herzegovina has not changed substantially since the end of the war. Nationalist narratives still dominate the public sphere and speaking out loud about rescue and help cannot be taken for granted to this day. ${ }^{33}$

Precisely because of these difficulties, it is remarkable that so many initiatives have been launched and developed, that these efforts started very soon after the war and have also experienced a certain continuity and development. Despite the lack of contact and coordination between the different activities, they show a lot of similarities and can be seen as varying contributions to a common goal: to change Bosnia-Herzegovina's current situation and build up trust, reconciliation and peace by publicly promoting the memory of interethnic help and rescue. In 2000, Svetlana Broz stated that her book illustrated 'the value of the positive example as a new method of working toward reconciliation', ${ }^{4}$ and more than ten years later the PCRC developed 'Ordinary Heroes' as a peacebuilding project using 'stories of rescuer behaviour and moral courage to promote reconciliation and interethnic cooperation'. ${ }^{35}$ In

31 RDC, The Signals of Heart, 18-19.

32 RDC, The Signals of Heart, 28.

33 Significantly, the authors who between 2017 and 2018 realized the project 'Human Examples in an Inhuman War' (see above) dedicated one section of their film to the question: Why is it so difficult to find interlocutors on this topic? Cf. Humani primjeri nehumanog rata. Šta kažu psiholozi?, Frontal, 23 March 2018, http://www.frontal.ba/novost/91389/humaniprimjeri-nehumanog-rata-sta-kazu-psiholozi. On the domination of nationalist narratives in postwar Bosnia-Herzegovina, cf. Nicolas Moll, Fragmented Memories in a Fragmented Country. Memory Competition and Political Identity-Building in Today's Bosnia and Herzegovina, Nationalities Papers 41, no. 6 (2013), 910-935, DOI: 10.1080/00905992.2013.768220.

34 Svetlana Broz, Courage, Truth and Reconciliation, Lecture at Harvard University, Educazione E Scuola, 15 November 2000, http://www.edscuola.it/archivio/interlinea/broz.html.

35 Bidley, Post-Conflict Research Center Wins Intercultural Innovation Award; also cf. RDC, The Signals of Heart, 198. Besides reconciliation and peacebuilding, another aim highlighted by several of the named initiatives is to promote the value of civil courage in Bosnia-Herzegovina. This is often also linked to the declared necessity of building a peaceful and democratic society. Cf., for example, Broz/Butler, eds, Having What it Takes. 
order to achieve this goal, the initiatives organize activities involving books, films and conferences, as well as educational tools directed at young people. ${ }^{36}$ Together, these initiatives have produced an important corpus of stories of help and rescue in relation to the Bosnian war. The three mentioned books alone contain more than 150 testimonies, and more have been collected but not yet published..$^{37}$

Most of the published stories have several points in common. They all include a life-saving rescue, but also simpler acts of help and solidarity; they all include diverse cross-ethnic constellations-Bosniaks helping Serbs, Serbs helping Croats, and so on-and their focus is not so much on the rescuers themselves as on the relationship between the helpers and the helped. Unlike the 'Righteous Among the Nations', the three books' tables of content already make clear that the focus is not on the rescuer alone. Each story is presented as a chapter, but not each chapter title includes a name; where a name appears, it is not necessarily that of the rescuer, but rather of the person telling the story. He or she may be a rescuer, but is often a recipient of assistance, and sometimes a family member of the helper or the helped. In other words, several of the initiatives mentioned above, and especially the books, are not so much attempts to publicize the names of individual rescuers, but rather individualized stories of rescue. Another characteristic element is that the stories include several examples of 'two-way' rescue in which the same person appears as both the beneficiary of aid and the provider of help.

Given these tendencies, one case appears exceptional, also with regard to the described difficulties of promoting 'positive stories'. It concerns Srđan Aleksić, a young Bosnian Serb from Trebinje, who on 21 January 1993 intervened to protect a Muslim acquaintance, Alen Glavović. The latter was attacked on the central square of Trebinje by a Bosnian Serb soldier. Thanks to Aleksić's intervention, Alen Glavović managed to escape, but Aleksić was beaten so severely by several soldiers that he died a few days later. Like many other stories, this one remained largely unknown for some time. In 2007, however, Aleksićs name and action were spectacularly brought to public attention when a documentary about him on Serbian state television popularized his story. Since then, many initiatives have honoured Aleksić in Bosnia-Herzegovina, Montenegro, and especially Serbia, organized by civil society actors, public authorities, and political actors from different sides. Even a feature film

\footnotetext{
${ }^{36}$ For example, the PCRC regularly organizes educational activities. Cf. PCRC, Ordinary Heroes Peacebuilding Programme, http://www.p-crc.org/our-projects/ordinary-heroespeacebuilding-program.

${ }^{37}$ Džemal Sokolović collected 'more than 500 testimonies about good deeds performed across ethnic/religious lines in the course of the war in Bosnia'. Sokolović plans to publish them, but the realization of the project has been postponed. E-mail correspondence with Džemal Sokolović, 25 June 2016.
} 
was produced in 2013 based on the story of Aleksić: 'Circles' by Serbian director Srdan Golubović. Aleksićs name and story have also been used in the framework of several of the aforementioned initiatives and have come to constitute an integral part of efforts to promote rescuer stories. ${ }^{38}$ At the same time, this case is specific in comparison to most other rescuer stories made public by civil society actors in Bosnia-Herzegovina because it focuses on just one person, has become so well known, and has been publicized not only by civil society actors and not only in Bosnia-Herzegovina. ${ }^{39}$

\section{Overcoming the Focus on Guilt and Victimhood? The Motivations of Civil Society Actors}

Beyond the aim of fostering reconciliation, what are the motives of civil society actors in calling attention to the memory of helpers and rescuers in Bosnia-Herzegovina? And how are these motives and aims linked to paradigms of guilt and victimhood, and to the figures of perpetrators and victims? The war in Bosnia-Herzegovina was the most violent of the Yugoslav wars of dissolution: around 100,000 people were killed, two million were displaced or became refugees (out of a total population of four million), around 200,000 persons were placed in detention camps, and an estimated 40,000 women were raped. The war was accompanied by strong polarization along ethnonational lines. The dominant discourse within each of the communities portrayed its own as the victim of aggression and of violent crimes committed by the other ethnic group(s). In 1995, the war ended with the Dayton Peace Agreement which institutionalized and perpetuated the ethnonational divisions between the three 'constituent peoples': the Bosniaks, the Croats, and the Serbs. In this framework, the remembrance of the war continued to be largely dominated by polarized and polarizing narratives in the public sphere, with a strong focus on victims and perpetrators and 'us vs them' narratives. ${ }^{40}$

In three respects, the efforts to publicize stories of help and rescue have constituted a firm reaction to this situation. Firstly, the civil society actors working to make these stories known to the public insist on how much they have been motivated by the will to counter the almost exclusive focus on the crimes and atrocities of the war in public discourse, especially in the media. 'The

\footnotetext{
${ }^{38}$ Aleksić's story is told in RDC, The Signals of Heart, 167-173. In 2012, the PCRC created a 'Srđan Aleksić Youth Competition', PCRC, Srđan Aleksić Youth Competition, https://www.p-crc.org/our-work/creative-multimedia/digital-media/srdjan-aleksic-youthcompetition/.

${ }^{39}$ For details, cf. Moll, A Positive Hero for Everyone?

${ }^{40}$ Cf. Ahonen, Coming to Terms with a Dark Past, 120-145; Moll, Fragmented Memories in a Fragmented Country.
} 
media reported only about the horrors of war; no one dealt with anything else but these horrors,' Svetlana Broz mentioned as a major motivation for initiating her project. ${ }^{41}$ Jezdimir Milošević argued similarly that 'everybody was talking only about the crimes, but nobody about positive examples'. ${ }^{42}$ Džemal Sokolović also expressed himself along such lines. Emphasizing that 'the war was not only a theatre of crime but that of magnificent acts of good as well', he has explained how his film should be seen as 'a warning that we are too much focused on the evil and war criminals, while forgetting the good which was simultaneously taking place, by good people whose deeds must not be forgotten'.43

Secondly, there is a strong will, through the publicized stories, to counter the narrative of the war as an ethnic conflict between irreconcilable communities and dominated by ancient hatreds, as well as to counter the idea that the coexistence of the different communities was or has become impossible:

'The stories that we have collected [...] unravel stereotypes and show that there are people who not only believe in coexistence, but are also in favour of preserving the tradition of such a lifestyle, and ready to risk their own lives. On the other hand, we believe that preserving these stories from oblivion, as well as their public affirmation, will help restore confidence among the citizens of our country. ${ }^{\prime 4}$

The intention behind the stories is to show that the idea of the 'good neighbourhood' continued to exist during the war, and that the war was unable to destroy this idea. It is communicated as a message of reconciliation and hope for the present and the future. An explanation as to why many initiatives have insisted so hard on the telling of stories, and not just on publicizing the names of rescuers, can be found in this context: if reconciliation is to be achieved, extraordinary actions and individuals are apparently less needed than stories of 'normal people' and their good relations. Thus, it is possible to demonstrate that while what these people did during the war was indeed very brave, at the same time it was not exceptional in the context of their prewar lives. In other words, the stories should show that cross-ethnic solidarity was normal in Bosnia-Herzegovina before the war, continued to exist despite the war, and could not be destroyed by the war. Consequently, they present living together as possible after the war. In this context, it is significant that the interviews conducted by the Research and Documentation Center follow a three-phase structure: 1 . life before the war; 2 . the war and events related

\footnotetext{
${ }^{41}$ Interview with Svetlana Broz. Dobri ljudi u vremenu zla, Aimpress, 4 March 1999, http:// www.aimpress.ch/dyn/pubs/archive/data/199903/90304-003-pubs-sar.htm.

${ }^{42}$ Interview with Jezdimir Milošević, East Sarajevo, 4 September 2013.

${ }^{43}$ Džemal Sokolović on his documentary 'And There Was Light'. The text appears at the end of the YouTube clip, cf. And There Was Light.

${ }^{44}$ RDC, The Signals of Heart, 17.
} 
to the good deed; 3 . life after the war and reflection on the importance of the good deed. ${ }^{45}$ And indeed, most of the interviewees consider the good relations they enjoyed before the war as a major factor leading to the positive act during the war, and express their confidence and hope that good neighbourly relations can persist. Many of the publicized stories are also stories of neighbours helping neighbours, thus countering the often circulated image of 'neighbours killing neighbours' during the Bosnian war. The stories therefore underline the importance and persistence of komšiluk, the traditionally good relationship between neighbours (of different religious or ethnic backgrounds) in BosniaHerzegovina. ${ }^{46}$

Consequently, it is understandable why most of the individuals and organizations involved in recording memories endeavour to present stories of help and rescue from each ethnic group, and try to be as balanced as possible. Of the ninety stories in the book 'Good People in an Evil Time', a third are told by members of the Bosniak community, a third by Bosnian Croats and a third by members of the Bosnian Serb community. Similarly, the film 'And There Was Light ...' represents three cases of rescue, featuring a Bosnian Serb, a Bosnian Croat and a group of Bosniaks. An exception is the series 'Living Together', which mainly presents Serbs as helpers or rescuers, presumably because the senior producer of this series does not originate from Bosnia-Herzegovina, but Serbia.

The will to promote coexistence also explains why the act itself, and the relationship between the rescuer and rescued, stand in the foreground rather than the rescuer alone. Two details are significant here. In the book 'The Signals of Heart', the last eighteen stories are actually nine stories told from two perspectives: that of the person who was helped, and that of the helper. In addition, several of the documentaries made by the Post-Conflict Research Center carry titles in which two names appear, for example: 'Zoran and Azra', 'Jagoda and Hamdija'. ${ }^{47}$ This choice underlines the intended focus on the relationship between two persons, while it is also striking that the title alone does not indicate which person had the role of rescuer or the rescued. It is also significant that the titles of these documentaries comprise first names only, emphasizing the proximity between the two persons. At the same time, the

\footnotetext{
${ }^{45}$ RDC, The Signals of Heart, 21.

${ }^{46}$ On komšiluk and its importance as a social practice, cf. Xavier Bougarel, Voisinage et crime intime, Confluences Méditerranée 64, no. 1 (2008), 83-98; Cornelia Sorabji, Bosnian Neighbourhoods Revisited. Tolerance, Commitment and Komšiluk in Sarajevo, in: Frances Pine/João de Pina-Cabral, eds, On the Margins of Religion, Oxford 2008, 97-112. Baskar addresses the possible link between komšiluk and acts of help and rescue during the Bosnian war, cf. Baskar, Komšiluk and Taking Care of the Neighbor's Shrine in Bosnia-Herzegovina, 65-67.

${ }_{47}$ PCRC, Ordinary Heroes.
} 
first names usually suffice to reveal the person's ethnic identity, thus underlining the cross-ethnic character of the story.

Additionally, the books 'Good People in an Evil Time' and 'The Signals of Heart' contain not only stories of cross-ethnic help in all constellations, but in several of the stories the same person figures both as a recipient and a provider of help. ${ }^{48}$ This contributes to spread a message of strong, mutual interethnic solidarity, countering the idea that the war destroyed any idea of living together. ${ }^{49}$

The third motivation behind efforts to publicize stories of help and rescue in Bosnia-Herzegovina is the endeavour to de-collectivize guilt. The dominant discourses have tended to collectively blame the other ethnic group(s) for perpetrated crimes. Working to counter such collective stereotyping, Protektor, for example, in its statutes explains that the publication of the collected 'positive stories' has 'the goal of presenting evidence against the thesis that all members of any ethnic group in Bosnia-Herzegovina are responsible for the committed war crimes'.50 'Often politicians or members of the clergy blame one specific ethnic group altogether, and yet atrocities happened everywhere. The prospective [sic] of the Righteous helps us focus on the individual,' explains Svetlana Broz. ${ }^{51}$ And in the foreword to the French edition of 'Good People in an Evil Time', Paul Garde points out that the 'big lesson' to be drawn from the testimonies is that 'there are "good people" everywhere, and also bad people everywhere'. ${ }^{52}$

In short, the efforts to bring rescuer stories to the attention of the public do not aim to duplicate and perpetuate the dominant victim-perpetrator dichotomy, but to work towards overcoming society's fixation on it. 'The focus is on good people, rather than on victims, perpetrators and ethnonationalist groups, and this aids the building of confidence, social action and collaboration', states Broz. ${ }^{53}$ And Leslie Woodward of the PCRC explains: 'Instead of focusing on the omnipresent "victims vs perpetrators" narratives, we focus on narratives of conflict that unite people. ${ }^{54}$

\footnotetext{
${ }^{48}$ Broz, Des gens de bien, includes more than twenty stories of this kind, for example 103106, 109-114, 130-135, 145-149, 321-322, 353-356.

${ }^{49}$ Significantly, the statement 'We helped each other' appears in several testimonies, cf. for example Broz, Des gens de bien, 97, 123, 261.

${ }^{50}$ Protektor, Statutes, Sarajevo 1997 [transcript in possession of N. M.].

${ }^{51}$ Broz, The Righteous Will Help Bosnia.

${ }^{52}$ Broz, Des gens de bien, 10.

${ }^{53}$ Svetlana Broz, Civil Courage. Good People in an Evil Time, Building and Promoting Resilience, African Health Sciences 8 (2008), 37-38, http://www.bioline.org.br/request?hs08063.

${ }^{54}$ E-mail correspondence with Leslie Woodward, 11 July 2016.
} 
Does this focus on 'positive stories' imply that there is little mention of the committed crimes, their perpetrators and victims? There is no unanimous answer. In the books 'Good People in an Evil Time' and in 'The Signals of Heart', many of the collected stories very explicitly do refer to and describe crimes and dramatic events in detail. Here, the focus on 'positive stories' does not in any way exclude talk about the crimes, on the contrary. Jezdimir Milošević takes a different approach. 'Crimes and good things are two sides of the same coin', he explains, but since the public sphere is so much dominated by the discourse on crime, he emphasizes that he prefers to insist on the 'positive' side: 'I want the people reading the book to get a positive feeling out of it. ${ }^{55}$ Consequently, none of the stories presented in 'Lights in the Tunnel' ends with the death of the helper or the helped person.

In contrast, two of the three cases featured in the film 'And There was Light...' end tragically for the rescuers, who are killed after and because of their deed. For the author of the film, Džemal Sokolović, the reason for choosing these stories was not so much to include the dramatic dimension of the war, or to highlight the heroism of the rescuers. Rather, he selected them to protect other helpers who survived the war, given that they are often still considered traitors by members of their own community: 'It is still a risk to talk about those who did good deeds. That is why I chose to speak about persons who are no longer alive.' 56

The producers of the series 'Living Together' have yet another reason to address the crimes: fear of being accused of downplaying them. This is certainly linked to the fact that the senior producer is from Serbia. When it comes to the film 'Neighbours', this is especially true. The film is dedicated to acts of help and rescue during the murderous campaign of ethnic cleansing against non-Serbs in Prijedor in 1992. In a press release, the producers explained that they wanted to tell these stories in order to strengthen trust and reconciliation processes, and that they wished to do so 'without relativizing or mitigating responsibility for what happened'. ${ }^{57}$

It is also worth noting that in all three books mentioned above, many of the stories are told from the perspective of the person who was in danger and received assistance. Thus, the perspective of the victims has not been neglected, quite to the contrary. 'The importance of these stories', emphasizes the RDC, 'is also the possibility they are giving us to learn certain facts about the war, which their narrators, particularly those who were victims, experi-

\footnotetext{
55 Interview with Jezdimir Milošević, East Sarajevo, 4 September 2013.

56 Interview with Džemal Sokolović, Sarajevo, 12 April 2014.

57 Projekat 'Živjeti zajedno', Bhnovinari, 14 August 2014, https://bhnovinari.ba/bs/2014/ 08/14/projekat-qivjeti-zajednoq/.
} 
enced. ${ }^{58}$ But do victims remain victims once they have experienced help and rescue? Generally, the aided individuals acquire an ambiguous status in the 'positive story' narratives. On the one hand, they figure as victims. The RDC in particular repeatedly uses this term, which is understandable for two reasons: why would people be helped if they had not become-or were in danger of becoming-victims of a crime? And why should a person rescued from death, but nevertheless endangered and forced to leave his or her home to survive, no longer be considered a victim $2^{59}$ On the other hand, the people helped in the stories often appear as 'untypical' victims or as individuals beyond the state of victimhood. This occurs in different ways. Firstly, through the act of help, the beneficiary's situation and experience differ from those of the victims who did not receive assistance. Secondly, the fact that those helped often became helpers and rescuers themselves indicates that they did not remain in a passive state of victimhood. Thirdly, the beneficiaries of help tell and share their stories about the good deed they experienced. They do so openly, and in the books and documentaries mentioned above, in a manner that usually avoids expression of self-pity or blame, and within the framework of a project that transmits a positive message of coexistence. This suggests that these people have left their initial state of victimhood, and have become agents and advocates of positive change in society. In this sense, it follows that Svetlana Broz explicitly characterizes not only those who helped, but also those willing to talk about the help they experienced, as 'good people'..$^{60}$

While the helped persons thus obtain an ambiguous status, the helpers and rescuers are usually referred to unambiguously as 'good people', ${ }^{61}$ 'good Bosnians, ${ }^{\prime}{ }^{62}$ 'ordinary heroes, ${ }^{\prime 63}$ examples of 'goodness and brotherhood [...] in the midst of barbarity and insanity', ${ }^{\prime 4}$ 'human beings who remained human beings [...] in ugly times', ${ }^{65}$ or 'heroes who defended [Bosnian society] [...] with decency, dignity, morality and by rejecting hatred and humiliation'.66 Thus, they are presented as a clear anti-model to the perpetrator. They are active, distinguishing them from the victim, and they are moral, distinguishing them from the perpetrator. Even if they died as a result of their action, in the narra-

\footnotetext{
${ }^{58}$ RDC, The Signals of Heart, 17.

${ }^{59}$ Examples of stories in which rescued persons are driven from their homes or suffer other losses can be found in RDC, The Signals of Heart, 49-52, 53-56, 57-62, 63-66, 67-70.

${ }^{60}$ Broz, Des gens de bien, 20.

${ }^{61}$ Broz, Good People in an Evil Time.

${ }^{62}$ RDC, The Signals of Heart, 12.

${ }^{63} \mathrm{Cf}$. the PCRC website.

${ }^{64}$ Neil J. Kritz/ Jakob Finci, A Truth and Reconciliation Commission in Bosnia and Herzegovina. An Idea Whose Time Has Come, International Law FORUM du droit international 3, no. 1 (2001), 50-58, 53.

${ }^{65}$ Lazar Manojlović, Zapisi iz vremena zla, Sarajevo 2009, 9.

${ }^{66}$ RDC, The Signals of Heart, 298.
} 
tives they are not reduced to the state of victim: they were killed for actively helping another person and while performing a positive deed. The aim of their stories is to emphasize the good deed and the positive message in which their dramatic death is embedded. ${ }^{67}$

\section{Responses to 'Positive Stories'. The Difficulty of Escaping the Victimhood vs Guilt Dichotomy}

Although the promoters of the rescuer narrative widely aim to overcome the dominant focus on guilt and victimhood, they are not always successful, as is shown by the reception of these narratives in the public sphere. In fact, these dominant patterns influence the discussion strongly. Reactions are often sceptical and negative, and here two basic forms can be distinguished. Firstly, apprehension about the fact that reports of help and rescue may provide too positive an image of the war and appear to deviate and distract from the essential, i.e. the committed crimes. Such reactions have led several people who received help during the war to refuse the publication of their stories. According to the RDC report,

'some recipients of assistance declined to participate in the project, because they believed that speaking publicly about positive acts that happened during the war, carried out by members of other ethnic groups, minimizes the negative deeds of other members of that ethnic group, which they saw as having been many more. ${ }^{\prime 68}$

On the other hand, the communication of information about rescuers to the public has triggered stronger, hostile reactions for the opposite reason: it is perceived to attract attention to the crime and explicitly or implicitly point to the perpetrators and accuse one side in the conflict. The reactions to the story of Nedeljko 'Neđo' Galić are particularly instructive in this context. During the war, Neđo Galić lived in the small Herzegovinian town of Ljubuški, not far from Mostar. The town was controlled by the 'Croatian Defence Council' which in 1993 decided to deport the Muslim population-mainly to the nearby Heliodrom internment camp. Neđo Galić, himself a Bosnian Croat, disagreed with this policy. As the only way out of the camp was a guarantee letter from abroad, which most of the inmates were unable to obtain, Galić issued hundreds of false documents. Thanks to his action, more than 1,000 people were released from the camp and able to travel safely to Germany and other countries. This story remained largely unknown to the wider public until Gariwo

\footnotetext{
${ }^{67}$ Cf., for example, the story of Goran Čengić as told by his mother, Nataša Čengić: 'I always like to talk about my Goran because I feel that, in a way, he wants me to talk about him and the good actions of people during the war,' RDC, The Signals of Heart, 135.

${ }^{68}$ RDC, The Signals of Heart, 29.
} 
in 2011 decided to honour Neđo Galić posthumously. They produced a documentary film about him and his story titled 'Neđo from Ljubuški', in which his widow, Stefica Galić, and others talk about him and his attitude during the war. ${ }^{69}$ The film premiered in Ljubuški and provoked very hostile reactions in Bosnian Croat nationalist circles. Several internet portals launched violent attacks against the movie and personal threats against Svetlana Broz and Stefica Galić. Galić was openly attacked and insulted in Ljubuški after the screening of the film. The two women were accused of dragging Bosnian Croats through the mud, and their attackers denied that the ethnic cleansing of non-Croats had taken place. They even accused Svetlana Broz of spreading 'ethnic hatred'. ${ }^{70}$

How reactions to rescuer stories have differed, and to what extent these stories are entangled with patterns of guilt and victimhood, is also illustrated in the mentioned case of Srđan Aleksić. One of the main reasons why his story has become so popular in Serbia is certainly that it promotes an image of the 'good Serb', thus countering the negative picture of Serbia in relation to the wars of the 1990s. It can therefore be seen as a tool of distraction from guilt, and has been partially criticized for this reason..$^{71}$ At the same time, however, some Serb and Bosnian Serb nationalist circles have also rejected this story, because they think it reinforces the perpetrator image of the Army of the Republic of Srpska and of Serbs in general. Bosnian Serb soldiers had attacked Glavović and then Aleksić. For example, the war veterans' association of Trebinje called for a boycott of the movie 'Circles' based on Aleksić's story. ${ }^{72}$

In fact, this movie is a good illustration of how differently Aleksić's story has been perceived, as is reflected in various statements by the director, Srdan Golubović. On the one hand, Golubović has expressed himself in ways that appear to attempt to whitewash Serbia of its negative image: 'I think that, after all these years, Srđan Aleksić helps to present our nation in the best light [...]. "Circles" has presented the world with Serbs as it has not seen them before."73 On the other hand, his film does not avoid addressing issues of guilt and victimhood. Firstly, 'Circles' clearly shows who the perpetrators were-Bosnian

\footnotetext{
${ }^{69}$ The film (47 $\mathrm{min}$ ) can be viewed on YouTube, cf. Nedjo of Ljubuski. Long Documentary, YouTube, http://www.youtube.com/watch?v=ryyb-yUzieU. Neđo Galić died in 2001.

${ }^{70}$ Cf. Ina Vukić, Josip Broz Tito's Granddaughter Trying to Prevent Further Investigations into Communist Crimes, 17 July 2012, https:/inaVukić.com/2012/07/17/josip-broz-titosgranddaughter-trying-to-prevent-further-investigations-into-communist-crimes/; Gariwo, Hatred of Svetlana Broz and/or Hatred of Civil Courage, press release, 17 February 2012, http://www.gariwo.org/en/news-and-events/news/hatred-of-svetlana-broz-and-or-hatredof-civil-courage.

${ }^{71}$ Details in Moll, A Positive Hero for Everyone?, 12, 16.

72 Moll, A Positive Hero for Everyone?, 16-17.

${ }^{73}$ Srdan Golubović, Moja lična pobeda, Vreme, 21 February 2013, 46-49, 47-48.
} 
Serb soldiers-and stresses that the original victim, Alen Glavović, was attacked just for being a Muslim. Secondly, among the characters whose stories are told in the movie is a perpetrator, as well as a passive bystander: a doctor who assists the attacks by not intervening. As Golubović explained in an interview: "Circles" is a film about guilt. It asks whether only those who committed the crime are guilty, or also those who witnessed the crime and failed to prevent it.' ${ }^{74}$ Golubović explicitly raises this question of the responsibility of 'bystanders' with a view to Serbian society and his own stance while the war in Bosnia-Herzegovina was being waged: 'That is the position of all of us here who did not participate in the war, but lived a mere 100 kilometres from the war zones, and who engaged in antiwar protests in the streets from time to time, but otherwise did nothing. ${ }^{75}$

The case of Srđan Aleksić is also relevant for another reason. While many civil society actors have presented his story as a model of reconciliation, others have used it instead to blame other ethnic groups. The newspaper Dnevni Avaz, for example, which is very much focused on Bosniak ethnonational interests and actively supports the promotion of Aleksićs story, wrote in 2011:

'Srđan Aleksić died resisting the fascist madness. He did not wish to succumb to it and to see this madness being carried out in his name. [...] Years after the event, the name of Srđan Aleksić has become a metaphor of resistance against fascist and nationalist madness. ${ }^{76}$

Obviously, here the focus on the 'one good Serb' serves to stigmatize Serbs in general and emphasize the guilt of the majority. As Jezdimir Milošević has observed: 'They only honour Srđan Aleksić in order to negatively show up the other Serbs. ${ }^{77}$ Yet, Aleksić's story has also been turned around to blame other ethnic groups. The leading political figure in the Republika Srpska, Milorad Dodik, in 2012 declared it important to honour Srđan Aleksić, adding: 'But unfortunately such examples did not exist on the other side. ${ }^{\prime 78}$ Dodik was obviously well aware that Aleksić's story can be directed against Serbs in general and Serb nationalism in particular, and he therefore attempted to deflect the question of guilt towards the other ethnic groups involved in the war.

\footnotetext{
${ }^{74}$ Martin Blaney, Circles, German Films Quarterly 2 (2011), 14, https://www.german-films. de/filmarchive/browse-archive/view/detail/pos/420/typ/browse/film/circles/index.html.

${ }^{75}$ Mladen Savković, Jedan vrlo, vrlo ... srpski film, B 92, 17 January 2013, https://www. b92.net/kultura/intervjui.php?nav_category=1081\&nav_id=678187.

${ }^{76}$ Elvir Huremović, Srdjanova poruka, Dnevni Avaz, supplement Sedmica, 29 January 2011, 7.

${ }_{77}$ Interview by N. M. with Jezdimir Milošević, East Sarajevo, 4 September 2013.

78 Orden Srđana Aleksića dar građanima, B 92, 15 February 2012, https://www.b92.net/ info/vesti/index.php? yyyy $=2012 \& m m=02 \& d d=15 \&$ nav_category $=12 \&$ nav_id $=582988$.
} 
The difficulty of transcending the dominant guilt-victimhood dichotomy when communicating rescuer stories is evident in a further case. In 1992, after around eighty Bosnian Muslims fled Bosnia-Herzegovina for Montenegro, the Montenegrin authorities sent them back to eastern Bosnia where most were killed by Bosnian Serb forces. In 2010, Gariwo honoured Slobodan Pejović, a former Montenegrin policeman who claimed that he had refused to take part in the deportation of the Bosnian Muslims and had helped some of them to escape. Since the end of the war, he had openly spoken out about this crime, despite many pressures against him. ${ }^{79}$ One year later, journalist Šeki Radončić investigated his case and subsequently made the documentary film 'A Hero of Our Time'. Here, he stated that the Muslims had not been helped by Pejović but by another policeman, and that Slobodan Pejović had falsely taken credit for this act. Moreover, he accused Pejović-despite Pejović's declarations to the contrary-of having been actively involved not only in the arrests, but also in the deportation of the refugees. ${ }^{80} \mathrm{~A}$ feud began between the supporters of the two contrasting narratives. On the one hand, Slobodan Pejović and Gariwo rejected the accusations, arguing that they were part of an effort to discredit Pejović for talking about war crimes in Montenegro. On the other hand, Šeki Radončić claimed that such arguments were evidence of the political endeavour to create a false 'national hero' with the ultimate goal of consolidating the myth of Montenegro's collective innocence with regard to the Yugoslav wars. ${ }^{81}$ Information relating to this case is very contradictory; it is difficult to determine what is fiction and what is fact. Without doubt, however, it illustrates how two sides can use a story of rescue in order to accuse the opposite side of relativizing guilt.

Similar reactions, to give another example, were provoked by the film 'Neighbours', produced in the framework of the documentary project 'Living Together'. The film tells the story of Dušan Radulović from Prijedor. In July 1992, the film relates, he saved several Croats from a neighbouring village from a murderous campaign of ethnic cleansing led by Bosnian Serb police forces. In April 2015, a public screening of this film was organized in Prijedor. During the discussion after the screening, and later in social media, Edin Ramulić, vice-president of the victims' association Izvor, strongly criticized the approach taken in the film. He pointed out that Radulović was accused of

\footnotetext{
${ }^{79}$ Montenegrin Policeman Honored For Refusing To Deport Muslims, Radio Free Europe, 9 February 2010, https://www.rferl.org/a/Montenegrin_Policeman_Honored_For_Refusing_ To_Deport_Muslims/1953438.html.

${ }^{80}$ The trailer for the documentary 'A Hero of our Time' (42 min) can be viewed on YouTube, https://www.youtube.com/watch?v=1MXtFEfUzdo.

${ }^{81}$ Cf., for example, Šeki Radončić, Anatomy of a Persecution, Cetinje 2014, where Radončić describes in detail his investigations concerning Pejović and the attacks directed against him.
} 
having killed two non-Serb neighbours on the very day on which he helped the Croats from the nearby village. In fact, this accusation is briefly mentioned in the film, but rejected by one of the witnesses. Although Ramulić did not deny that Radulović had hidden and saved civilians, he criticized that the film did not follow up the claims that he was also a perpetrator. ${ }^{82}$

The cases of Slobodan Pejović, accused of being a perpetrator and not a rescuer at all, and Dušan Radulović, accused of being not only a rescuer but also a perpetrator, shed light on the ambivalent figure of the perpetrator-rescuer, a topic usually avoided or downplayed by civil society actors aiming to promote 'positive stories' about the war. Such figures do not sit well with the stories' political and educational purposes. But as we have seen, this ambivalence sometimes pops up in public reactions, and there is also another domain into which this issue directly extends: the courtroom. This has been especially clear in trials at the International Criminal Tribunal for the former Yugoslavia (ICTY) in The Hague related to the Prijedor concentration camps established in 1992 by the local Bosnian Serb authorities, and in local courts. Several of those charged in these trials defended themselves by stating that they had helped Muslims in the camps or rescued them. Some Muslims also testified in court in favour of the defendants and confirmed their claims. ${ }^{83}$

These cases are usually not widely discussed-except in the local communities concerned-as they are very confusing and cross the clear-cut lines that commonly separate perpetrators and rescuers on the one hand, and perpetrators and the rescued victim on the other. Does the fact that a perpetrator was responsible for rescuing someone relativize the crimes they committed? And does a rescued victim have the moral right to support an indicted perpetrator knowing that while they were helped, the defendant was involved in the deaths of others? Among the survivor groups in Prijedor, individuals who agreed to testify were sometimes heavily criticized by other survivors, who accused them of supporting attempts to exculpate those on trial. ${ }^{84}$ In relation to the judgments, several verdicts did not refer to the acts of help or rescue underlined by the defence as a possible mitigating factor, such as the judgment in the trial against Miroslav Kvočka in November 2001 in which the

${ }^{82}$ Interviews by N. M. with participants at the public screening, Sarajevo/Prijedor, April 2015. On the projection of the film in Prijedor, cf. Katarina Panić, Slabo interesovanje u RS za film o dobrim delima u ratu, Balkan Insight, 22 April 2015, http://www.balkaninsight. com/en/article/slabo-interesovanje-u-rs-za-film-o-dobrim-delima-u-ratu.

${ }^{83}$ My thanks to Isabelle Delpla who turned my attention to these cases. For more details, cf. Isabelle Delpla, La justice des gens. Enquêtes dans la Bosnie des nouvelles après-guerres, Rennes 2014, 396-399, 470.

${ }^{84}$ Interview by N. M. with a representative of an association of former camp inmates in Prijedor, April 2013. 
ICTY did not consider the fact that he had rescued two Muslims. ${ }^{85}$ In the trial against Milorad Škrbić in October 2010 at the Court of Bosnia-Herzegovina, however, the court, which sentenced Škrbić to 22 years in prison, cited witness statements as a mitigating factor according to which Škrbić had protected a number of civilians in the bus he had escorted to the execution site. ${ }^{86}$ Thus, there is no consensual legal practice when it comes to evaluating perpetratorrescuer cases.

\section{The Remembrance of Rescuers. Comparing the Bosnian War to Other Occurrences of Mass Violence}

To what extent have the efforts to promote the memory of helpers and rescuers from the Bosnian war been influenced by the global acknowledgement of rescuers, and especially the 'Righteous Among the Nations'? Presenting her project for a 'Garden of the Righteous of the Bosnian War', Svetlana Broz refers explicitly to Yad Vashem. And the name of her NGO, Gariwo, reveals that it is part of the network 'Gariwo - Gardens of the Righteous Worldwide' founded in Milan, Italy, in 2001 by journalist and historian Gabriel Nissim with the aim of creating a network of similar projects in different countries and in relation to various conflicts.$^{87}$ Between 2013 and 2015, Gariwo organized annual award ceremonies in Sarajevo on 6 March in response to the European Parliament's decision in 2012 to mark this day as the 'European Day of the Righteous' ${ }^{88}$

Jezdimir Milošević remembers that he did not know about the 'The Righteous Among the Nations' until he read about them in a Yugoslav newspaper in 1985. This discovery motivated him to later collect positive stories related to the Bosnian war. ${ }^{89}$ Other examples demonstrate that the remembrance of Holocaust-era rescuers, especially Oskar Schindler, have had a degree of influence in Bosnia-Herzegovina. Since the launch of Steven Spielberg's film 'Schindler's List' in 1993, Schindler has become a global reference figure beyond the Holocaust. In connection with the war in Bosnia-Herzegovina, the Schindler reference has been applied to Radomir Lakić from Brčko, whom local media

\footnotetext{
${ }^{85}$ Cf. International Criminal Tribunal for the Former Jugoslavia (ICTY), Judgement in the Case The Prosecutor against Miroslav Kvocka, Milojica Kos, Mlado Radic, Zoran Zigic and Dragoljub Prcac (Omarska/Keraterm/Trnopolje), press release, The Hague, 2 November 2001, http://www.icty.org/en/sid/7941. On how the 'good deeds' of defendants are used as a defence strategy and the ambiguities of this strategy, cf. Delpla, La justice des gens, 431-433.

${ }^{86}$ Cf. Denis Džidić, Koricanske stijene. A Total of 86 Years in Prison, detektor.ba, 21 December 2010, http://detektor.ba/en/koricanske-stijene-a-total-of-86-years-in-prison/.

${ }^{87}$ Gariwo Network, About us, https://en.gariwo.net/about-us-4969.html.

${ }^{88}$ European Parliament, Declaration of the European Parliament of 10 May 2012.

${ }^{89}$ Interview by N. M. with Jezdimir Milošević, East Sarajevo, 4 September 2013.
} 
dubbed the 'Bosnian Schindler'.90 Neđo Galić from the Herzegovinian town of Ljubuški has been called 'The Schindler of Ljubuški'. ${ }^{91}$

Furthermore, in a photographic exhibition titled 'Rescuers', realized in cooperation with an American NGO, the PCRC showed portraits not only relating to the Bosnian war, but also to the Holocaust, Rwanda and Cambodia. ${ }^{92}$ Last but not least, international organizations that have supported the BosnianHerzegovinian initiatives were partially inspired to do so because they linked the Bosnian experience to the rescue of Jews during the Holocaust. ${ }^{93}$

Nevertheless, the emergence of the rescuer topic in Bosnia-Herzegovina has not been a copy of the global commemoration of the 'Righteous'. Even if these forms of remembrance have inspired some of the active memory entrepreneurs in Bosnia-Herzegovina, their efforts to make the stories of rescuers known have developed in a sui generis manner and with their own local specificities. As illustrated above, remembrance here is not so much about the individuality of the rescuer, but rather the links between those who provided and those who received assistance. Also, the rescue stories involve all cross-ethnic constellations including Bosniaks, Croats, and Serbs. This is different in most other cases. Rescue discourses related to the Holocaust, Rwanda, and Armenia usually clearly and distinctly attribute the rescued to one ethnic, religious or national group, while another group has the role of rescuer: Jews/non-Jews, Tutsi/Hutu, Armenians/non-Armenians.

Also, although they are sometimes named, explicit references to the 'Righteous' do not constitute a dominant pattern in efforts to promote 'positive stories' from the Bosnian war. Interestingly, none of the authors of the three books mentioned above-'Good People in an Evil Time', 'Light in the Tunnel', and 'The Signals of Heart' - draw any comparison in their forewords to other countries, or make any reference to the 'Righteous'. Links to the memory of

${ }^{90}$ Vesna Orlović, Radomir Lakić. Bosanski Schindler. Srbin koji je 1992. u Brčkom spasio 70 Bosnjaka, Brčanske Novine 42, 27 March 2008, 9-10. My thanks to Cécile Jouhanneau for drawing my attention to Radomir Lakić.

${ }^{91}$ Cf. for example Ante Tomić, Ljubuški Schindler, Jergovic, 31 July 2012, http://www. jergovic.com/ajfelov-most/Ljubuški-schindler/. A Sarajevo newspaper that published an article about the documentary series 'Living Together' used the title 'The Bosnian Schindlers', cf. Maja Radević, Bosanski Šindleri, Slobodna Bosna, 19 March 2015, 44-47.

${ }_{92}$ For more information about the 'Rescuers' exhibition, cf. PCRC, The Rescuers. Stories from BiH, Rwanda, Cambodia, and the Holocaust, 2011, https://www.p-crc.org/our-work/ creative-multimedia/photography/the-rescuers-stories-from-bih-rwanda-cambodia-andthe-holocaust/.

${ }_{93}$ For example, in the foreword of the French edition of 'Good People in an Evil Time', published with the support of the Rhône-Alpes region, the editor explains that the motive for supporting the book was linked to the region's own history. It had been 'witness to numerous acts of courage by inhabitants of the Rhône-Alpes region, who had risked their lives in order to rescue Jews and others who were persecuted by the Nazis'. Cf. Broz, Des gens de bien, 3 . 
the Bosnian 'Righteous' of 1941-1945 are scarce, too, a point to which I will return below.

What other differences and similarities can be established between public discourses about rescuers in the Bosnian war and those in other contexts of war and mass violence, and especially in relation to discursive patterns concerning guilt and victimhood? The issue of whether the public remembrance of rescuers distracts from the related crime, and thus constitutes a tool of exculpation, regularly appears in other contexts, too, and especially concerning the rescue of Jews. A recent example is the public controversy in 2018 over the so-called Holocaust Law in Poland. The conservative Polish government insisted emphatically on the importance of Polish rescuers during the Holocaust in an obvious attempt to downplay the role of antisemitism in Polish society. ${ }^{94}$

The issue of false rescuers is also known in other contexts. Giovanni Palatucci, for example, was credited with having saved several thousand Jews between 1940 and 1944 while working as police officer in Rijeka (Italian: Fiume). After the war, he was celebrated as a national hero in Italy and declared 'Righteous Among the Nations' by Yad Vashem in 1990. In 2013, however, Italian scholars revealed that not only was there no evidence that Palatucci had saved Jews, the documents show that he had helped the Nazi regime to identify Jews and send them to death camps. The promotion of his memory after the war was now attributed to the deliberate spreading of the myth of 'the good Italian'. ${ }^{95}$

The ambivalent figure of the perpetrator-rescuer has recently also drawn strong interest in other contexts, especially that of Rwanda, giving rise to the question of whether a clear distinction is possible between 'perpetrators who commit crimes' on the one hand, and 'rescuers who rescue from the crime' on the other. ${ }^{96}$ More generally, the promotion of rescuers over the last three decades-similarly to Bosnia-Herzegovina-has reflected a desire to avoid blackand-white perceptions of mass violence. Rather, attempts have been made to bring more complexity to the field of human attitudes and actions when faced

\footnotetext{
${ }^{94}$ Cf. Allison Kaplan Sommer, From \#GermanDeathCamps to \#PolishRighteous. Poland Launches Social Media Campaign to Defend Its Controversial Holocaust Law, Haaretz online, 7 February 2018, https://www.haaretz.com/israel-news/.premium-poland-takes-tosocial-media-to-defend-its-controversial-holocaust-law-1.5803441.

${ }_{95}$ The Centro Primo Levi has gathered several texts on the topic, http://primolevicenter. org/?s=Palatucci; cf. Patricia Cohen, Italian Praised for Saving Jews Is Now Seen as Nazi Collaborator, New York Times, 19 June 2013, https://www.nytimes.com/2013/06/20/arts/ an-italian-saint-in-the-making-or-a-collaborator-with-nazis.html?_r=3\&.

${ }^{96}$ Cf. Lee Ann Fujii, Rescuers and Killer-Rescuers during the Rwanda Genocide. Rethinking Standard Categories of Analysis, in: Semelin/Andrieu/Gensburger, eds, Resisting Genocide, 145-158; Gudehus, Helping the Persecuted, especially the section 'Perpetrators Who Help, Helpers Who Abuse'.
} 
with mass violence. Such complexity clearly goes beyond exclusive perpetrator vs victim categories everywhere. ${ }^{97}$

The so-called 'bystanders' represent another issue. In other contexts of mass violence, especially the Holocaust, this category is as central as it is controversial. And it is tightly linked to the question of the rescuers. The focus on Holocaust rescuers has developed along with the growing attention paid to bystanders since the 1990s. In Raul Hilberg's seminal 'Perpetrators, Victims, Bystanders', rescuers are presented as sub-figures of the bystander. ${ }^{98}$ Other authors, when writing about the Holocaust, regularly oppose the dichotomy of (active) rescuers and (passive) bystanders as two distinctive responses to mass violence. They raise the question of the guilt and responsibility of (passive) bystanders by advancing examples of help and rescue which question the still persistent myth, in Germany and other European countries, that nothing could be done against the Nazi crimes. ${ }^{99}$

In the Balkans, the figure of the bystander in the Bosnian war does not constitute a central topic of public discussion. And it is only very rarely linked to the topic of helpers and rescuers. Although the PCRC theorizes the role of bystanders in conflicts and the question of 'bystander intervention' in its educational activities, this is usually not linked to the Bosnian war. ${ }^{100}$ As mentioned above, while the film 'Circles' does raise the question of bystanders, the concept is largely absent from public discourse around Srđan Aleksić in general. It is no coincidence that the question of 'bystanders' brought up by 'Circles' relates mainly to Serbia rather than Bosnia-Herzegovina, with film director Golubović addressing whether 'we in Serbia' could have done more to stop the war. Moreover, when the bystander question is raised in Bosnia-Herzegovina, it is usually reserved for the international community and its refusal to intervene militarily. ${ }^{101}$ The fact that the 'bystander in Bosnia-Herzegovina' is close to non-existent as a concept is mainly due to collective ethnic mobilisation during and after the war, and the strong focus on victims and perpetra-

\footnotetext{
${ }^{97}$ Cf., for example, Matthias Heyl, Warum sie den verfolgten Juden halfen. Die Retter, Die Zeit, 4 March 1994, https://www.zeit.de/1994/10/die-retter. Heyl writes that 'the Holocaust cannot be reduced to the dichotomy between perpetrators and victims'.

${ }_{98}$ Raul Hilberg, Perpetrators, Victims, Bystanders. The Jewish Catastrophe, 1933-1945, New York 1993, 195-268.

${ }_{99}$ On the question of how dealing with rescuers can contribute to the debate on bystanders, cf. Dudai, 'Rescuers for Humanity', 25-27. For a critical review of the bystander concept in recent Holocaust studies, cf. Christina Morina/Krijn Thijs, eds, Probing the Limits of Categorization. The Bystander in Holocaust History, New York/NY, Oxford 2018. I would like to thank Katrin Paehler for her valuable insights regarding this topic.

${ }^{100}$ Cf., for example, Post-Conflict Research Center Presents 'Ordinary Heroes' Project, Global Justice Academy Blog, February 2015, http://www.globaljusticeacademy.ed.ac.uk/ news/postconflict_research_center_presents_ordinary_heroes_project.

${ }^{101}$ Lučić, Bystanders in Bosnia and Herzegovina during the Conflict in the 1990s, 35-43.
} 
tors. In public discourse, each community sees itself primarily as the victim, and the other as the perpetrator. Given this clear-cut division between 'us and them', not much space is left to raise the issue of bystanders. ${ }^{102}$

A topic regularly raised in relation to the rescue of Jews during the Second World War is the alleged passivity of the Jewish victims. Stories about rescuers related to the Holocaust often construct a dichotomy between the active Christian rescuer and the passive Jewish victim who is saved. This dichotomy has come to be increasingly criticized as an undue reproduction of the traditional perception of Jews doing nothing to resist their extermination. ${ }^{103}$ There is no analogy to this in the Bosnian case, for two reasons. Firstly, victims and rescuers can be found in all cross-ethnic constellations. Secondly, the line of distinction between the rescuers and the rescued is often blurred, and the same person can appear to be both at the same time. This reduces the possibility of categorizing persons from one ethnic group as active rescuers and those of another group as passive victims. Given that the issue of victim passivity is usually not raised in the Rwandan, Armenian or Cambodian contexts either, it appears to be very specific to the remembrance of the Holocaust and the perception of the Jewish victims. Nevertheless, there have been conscious efforts to adjust this perception. One significant example is the 'Silent Heroes' memorial in Berlin. A new exhibition opened here in 2018, and while the former focused mainly on the rescuers of Jews, now attention is additionally drawn to the active role of Jews who went into hiding in order to survive. As the exhibition catalogue puts it, the memorial 'is dedicated to those who evaded the deadly threat and to those who helped them do so. ${ }^{\prime 104}$ International research, too, has in the last decade increasingly focused on the active role of Jews in their rescue, the interaction between the persecuted and their helpers, as well as the role of Jewish self-help, i.e. of how Jews helped other Jews. ${ }^{105}$

Looking again at Bosnia-Herzegovina, the close connection between rescuer and rescued and the pattern of the rescued becoming rescuer appears in another variation, too: the linking of the rescue of Jews in Bosnia-Herzegovina during the Second World War with the rescue by Jews during the war of

\footnotetext{
102 On the difficulties of applying the concept of bystanders to Bosnian-Herzegovinian society in relation to the 1992-1995 war, cf. Lučić, Bystanders in Bosnia and Herzegovina during the Conflict in the 1990s.

${ }^{103}$ Cf., for example, Renée Poznanski, Anti-Semitism and the Rescue of Jews in France. An Odd Couple?, in: Semelin / Andrieu / Gensburger, eds, Resisting Genocide, 83-110, esp. 110.

${ }_{104}$ Stiftung Gedenkstätte Deutscher Widerstand, ed, Gedenkstätte Stille Helden. Widerstand gegen die Judenverfolgung, 1933-1945. Katalog zur Daueraustellung, Berlin 2018, 7.

${ }^{105}$ For example, cf. Bob Moore, Survivors. Jewish Self-Help and Rescue in Nazi-Occupied Western Europe, Oxford 2010; Beate Kosmala, Überlebensstrategien jüdischer Frauen in Berlin. Flucht vor der Deportation, 1941-1943, in: Andrea Löw/Doris L. Bergen/Anna Hajkova, eds, Alltag im Holocaust. Jüdisches Leben im Großdeutschen Reich, 1941-1945, Munich 2013, 29-47; Jacques Semelin, La survie des Juifs en France, 1940-1944, Paris 2018.
} 
1992-1995. Until today, Yad Vashem has declared 43 individuals from BosniaHerzegovina, of all ethnic groups, as 'Righteous Among the Nations' for rescuing Jews between 1941 and 1945. Regularly, Bosnia's Jewish community, represented by its cultural advisor Eli Tauber, makes an effort to promote these stories. ${ }^{106}$ However, similarly to the publication of stories of rescue from the 1992-1995 war, these efforts remain rather isolated endeavours. The main reason why the memory of the rescue of Jews during the Holocaust is generally not very present in the Bosnian public space is that the memory of the Holocaust as such is not prevalent. Like the memories of 1992-1995, the memories of the Second World War are mainly focused on the three dominant ethnic groups.

Nevertheless, the two wars are sometimes connected to each other in rescuer narratives. In the book 'Good People in an Evil Time', the last story of assistance is mainly dedicated to the Jewish association La Benevolencija during the siege of Sarajevo between 1992 and 1995. This association distributed food and other items to all citizens, regardless of their ethnic identity. The person telling the story starts his testimony by evoking the memory of how his parents had helped Jews during the Second World War. ${ }^{107}$

The link between yesterday's rescued victim and today's rescuer is most evident in a story published by Eli Tauber, which over the years has been quoted several times by Bosnian media. During the Second World War, the (Muslim) Hardaga family in Sarajevo helped the (Jewish) Kabilio family to hide. The Kabilios escaped the Holocaust and later emigrated to Israel. In 1984, Yad Vashem recognized the Hardagas as 'Righteous Among the Nations'. During the war of 1992-1995 and the siege of Sarajevo, Zeineba Hardaga and her family were invited by the Israeli authorities to come to Israel, where they were met and helped by the Kabilio family. ${ }^{108}$ Because of its singularity, but also because it connects Jews and Muslims, this story about a 'family rescuing their rescuers' from Bosnia-Herzegovina gained international media attention. ${ }^{109}$

\footnotetext{
${ }^{106}$ Eli Tauber, When Neighbours Were Real Human Beings, Sarajevo 2010, depicts persons from Bosnia-Herzegovina recognized as 'Righteous Among the Nations' by Yad Vashem. In 2008, Eli Tauber also organized an exhibition on the topic, cf. Tauber, When Neighbours Were Real Human Beings, 79.

107 Broz, Des gens de bien, 417-419.

108 Tauber, When Neighbours Were RealHuman Beings, 40-43.Zeineba's daughter remained in Israel after the war, converted to Judaism, and found employment in the archives at Yad Vashem. Cf. Kako su se porodice Hardaga i Kavili spasile od sigurne smrti u dva rata, klix.ba, 9 April 2012, https://www.klix.ba/vijesti/bih/kako-su-se-porodice-hardaga-i-kavilispasile-od-sigurne-smrti-u-dva-rata/120409037.

${ }_{109}$ Cf., for example, Jerome Taylor, Divided by Faith, United by War, The Independent, 16 April 2010, https://www.independent.co.uk/news/people/news/divided-by-faith-unitedby-war-1946471.html; Ron Csillag, Family Rescues their Rescuers, The Canadian Jewish News, 18 November 2013, http://www.cjnews.com/news/family-rescues-rescuers. A doc-
} 


\section{Conclusion. The Potential of Rescuer Stories}

Public remembrance of help and rescue related to the Bosnian war presents both similarities and differences in comparison to other contexts of war and mass violence. Studying it represents a useful and stimulating contribution to the larger discussion about such memorialization on a European and global level, and in particular the question of how rescuer discourses relate to categories of crime and victimhood. In Bosnia-Herzegovina, rescuer discourses often insist on the equal treatment of the rescuer and the rescued. Also, they regularly present the same person and different communities in both roles. Both approaches thereby blur the perception of a clear-cut relationship between the rescuer and the rescued. The case of Bosnia-Herzegovina therefore also contributes to question the oversimplifying 'active rescuer' vs 'passive victim' paradigm on a more general level.

In relation to the topics of victimhood and guilt, the promoters of rescue stories in Bosnia-Herzegovina strive to confront and even overcome the focus on these categories, and to provide a more differentiated view of the realities of the war. At the same time, the tensions surrounding 'positive stories' of help and rescue in the public space illustrate how strongly entrenched attitudes of blaming and victimization continue to be. In fact, they continue to strongly influence discourses about people who provided help. This can also be attributed to the way in which civil society actors promote their rescuer stories, often embedding them in a 'good vs evil' narrative and thus basically replacing the victim vs perpetrator focus with another simplifying dichotomy. The war and the perpetrators are on the side of evil, and the rescuers and rescued on the side of good. No room is left for ambivalence or problematic aspects in connection with the actions of rescuers, thus enabling the creation of idealized heroes. This is a problem that concerns rescuer discourses beyond the Bosnian context, too. ${ }^{110}$

As we have seen, rescuer stories are not necessarily unequivocal in their message. They can be instrumentalized in ethnonational discourses in order to blame other groups, and in such cases help to reinforce existing divisions. On the other hand, the resistance and sometimes open enmity that rescuer stories encounter show that they are also perceived as a potential threat by nationalist circles. For the latter, interested in maintaining ethnic divides, narratives of blame and victimization are a crucial ingredient. Nevertheless, though stories of help and rescue partially risk reproducing or reinforcing discursive patterns of guilt and victimhood, they also open up other views of

umentary film has also been made about this story: 'The Woman from Sarajevo' (2007, 65 min) by Ella Altermann.

${ }^{110}$ Cf. Dudai, 'Rescuers for Humanity', 32-35. 
the past. They offer a tool for a more complex perception of the Bosnian war beyond its reduction to victims and perpetrators, and to three monolithic ethnic groups.

The potential of rescuer stories has been empirically investigated by social psychologist Sabina Čehajić-Clancy, who has evaluated some of the PCRC's educational activities in the framework of the 'Ordinary Heroes' project. Learning about rescuers positively changes intergroup relations and fractures monolithic perceptions of the 'Other'. ${ }^{111}$ Similar results have been observed by Polish researchers who have used rescuer stories in educational workshops with young Poles and Israelis, as well as in other national constellations. ${ }^{112}$

However, the organized and guided framework of educational workshops is just a beginning. More systematic research is needed on the impact of rescuer stories on postconflict societies, also within less structured frameworks. To what extent does reading or watching movies about rescue(rs) influence the perceptions of readers and viewers? Do understandings of war and mass violence, guilt and victimhood, perpetrators and victims change? This kind of research is lacking, not only on Bosnia-Herzegovina, but generally. Despite hundreds of studies dealing with 'Schindler's List', no systematic research has been undertaken on how this movie has affected its viewers. After watching the film, was their attention more focused-and in what way-on the rescue stories, on the crimes, or on both? Or did they retain something entirely different? A recent study of how audiences responded to films about the Holocaust can provide some first indications. Interestingly, although 'Schindler's List' was not among the analysed films, several of the interviewees referred to it more than once, thus underlining its central role as a reference point in relation to the Holocaust. Among other things, the viewers' remarks seemed to indicate that they mostly remembered the violence, or the victims, and less so Schindler himself or his acts of rescue. This appears to counter fears that this movie-and rescuer stories in general-could be seen by viewers as a tool for downplaying violence and relativizing guilt. ${ }^{113}$

\footnotetext{
111 Sabina Čehajić-Clancy et al., Social-Psychological Interventions for Intergroup Reconciliation. An Emotion Regulation Perspective, Psychological Inquiry 27, no. 2 (2016), 73-88, DOI: 10.1080/1047840X.2016.1153945; Sabina Čehajić-Clancy / Michal Bilewicz, Fostering Reconciliation through Historical Moral Exemplars in a Postconflict Society, Peace and Conflict. Journal of Peace Psychology 2, no. 3 (2017), 288-296, DOI: 10.1037/pac0000210.

${ }_{112}$ Michal Bilewicz / Manana Jaworska, Reconciliation through the Righteous. The Narratives of Heroic Helpers as a Fulfilment of Emotional Needs in Polish-Jewish Intergroup Contact, Journal of Social Issues 69, no. 1 (2013), 162-179, DOI: 10.1111/josi.12009; Marta Witkoswka et al., Fostering Contact after Historical Atrocities. The Potential of Moral Exemplars, Political Psychology 49, no. 3 (2019), DOI: 10.1111/pops.12529.

${ }^{113}$ Stephanie Rauch, Making Sense of Holocaust Representations. A Reception Study of Audience Responses to Recent Films, PhD thesis, University of Leicester 2014.
} 
Another interesting study that focused on viewer reactions to the movie 'Hotel Rwanda' seems to confirm this assumption. ${ }^{114}$ The film is based on an act of rescue that took place during the genocide against the Tutsi in 1994. Here, too, several of the responses by interviewees suggest that they were struck more by the scenes featuring violence than those featuring acts of rescue. Watching the movie therefore did not lead viewers to underestimate what happened in Rwanda, rather to the contrary. However, the central question of this study does not concern the film's reception as such, but what determines how viewers see the same film in different ways (indicating that reception is extremely diverse and to a large extent dependent on the socio-biographical background of the viewers). In addition, the study is based on a very small sample of viewers. Therefore, further research will be needed to explore this topic more deeply.

Meanwhile, the analysis of the Bosnian case enables the following general conclusion: it is not an alternative to ask whether rescuer stories distract from atrocities and war crimes or, on the contrary, attract attention to them. Rescuer stories have the potential to do both. Ultimately, the interpretation of rescuer narratives depends on the broader sociopolitical context, on the intention and perspective of the 'promoters' and the perspectives and attitudes of the 'recipients'. In this sense, it is also not an alternative to juxtapose stories of rescue as a tool to overcome the guilt-victimhood dichotomy with stories of assistance as a means of reinforcing this dichotomy. Rescuer narratives can do both, and both at the same time.

\section{CORRESPONDING AUTHOR}

Nicolas Moll Logavina 11, 71000 Sarajevo, Bosnia and Herzegovina. E-mail: moll.nicolas@gmail.com

${ }^{114}$ Christian Gudehus/Steward Andersen/David Keller, Understanding Hotel Rwanda. A Reception Study, Memory Studies 3, no. 4 (2010), 344-363, DOI: 10.1177/1750698010374923. 